Témoigner Témoigner. Entre histoire et mémoire

Getuigen Revue pluridisciplinaire de la Fondation Auschwitz

$123 \mid 2016$

Traduire le témoignage

\title{
Voicing the Perpetrator's Perspective: Translation and Mediation in Jean Hatzfeld's Une saison de machettes
}

Donner la parole au bourreau: Scénographie et traduction dans Une Saison de machettes de Jean Hatzfeld

\section{Anneleen Spiessens}

\section{OpenEdition}

\section{Journals}

\section{Electronic version}

URL: https://journals.openedition.org/temoigner/5249

DOI: 10.4000/temoigner.5249

ISSN: 2506-6390

Publisher.

Éditions du Centre d'études et de documentation Mémoire d'Auschwitz, Éditions Kimé

Printed version

Date of publication: 1 October 2016

Number of pages: $69-83$

ISBN: 987 2-9600926-4-6

ISSN: 2031-4183

Electronic reference

Anneleen Spiessens, "Voicing the Perpetrator's Perspective: Translation and Mediation in

Jean Hatzfeld's Une saison de machettes", Témoigner. Entre histoire et mémoire [Online], 123 | 2016,

Online since 02 November 2021, connection on 04 November 2021. URL: http://

journals.openedition.org/temoigner/5249 ; DOI: https://doi.org/10.4000/temoigner.5249 


\section{Voicing the Perpetrator's Perspective Translation and Mediation in.Jean Hatzfeld's Une saison de machettes}

\section{THE PERPETRATOR'S TESTIMONY}

(1) This and all subsequent translations from the French are mine.

\section{$\rightarrow$ Anneleen Spiessens Ghent University}

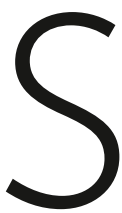

ince the 1980s, French literature has taken a "historical” turn, refocusing on the important events that have shaped the way we think about the world today, and on the personal experience of people who witnessed them. Dominique Viart, an influential literary critic and co-author of a "history" of contemporary French literature (Viart et al., 2008), has perceptively noted that French literature has abandoned in large measure the structuralist and avant-gardist formal experiments of the 1960s and 1970s to engage in what used to be the territory of the social sciences. He argues that contemporary literature has become "spectral" and "critical", showing a remarkable historical awareness not only of history in general but also of its own, literary, traditions. Accordingly, the "return" of the Subject and of History in the text cannot consist of a simple restitution of traditional engaged literature as it was once conceived by Sartre. Rather, these issues reappear as urgent, yet unresolved, questions which form a constant inspiration for writers - sometimes even the very raison d'être of their literature.

The genre of testimonial literature investigates this relation between history and narrative - witnessing and writing. In this genre, issues of biography and history are neither simply "represented" nor "reflected", but are "reinscribed, translated, radically rethought and fundamentally worked over" by the text (Felman et al. 1992, xiv-xv). The French historian Denis Peschanski reads the present success of the testimonial genre's focus on perpetrators of violence - following its focus on the resistance fighter of the immediate post-war era and the focus on the victim in the 1980s - as a sign of a change in "memory mode" (Devarrieux and Levisalles 2006). Writers in this genre, when interrogating the relation between past and present, embrace the dark pages and "black holes" of history that concern conflict, war, mass violence and genocide (Rotman 2005,17). ${ }^{1}$ They reflect on the questions of what to do and how to live "when, without any doubt, it is too late" (Gatore 2008, 10; see also Mauvignier 2009, 280).

In his frequently cited article on literary testimony, Michael Riffaterre established what have come to be accepted as the fundamental characteristics of the genre (Riffaterre 1995, 35): 
Voicing the Perpetrator's (continuation)

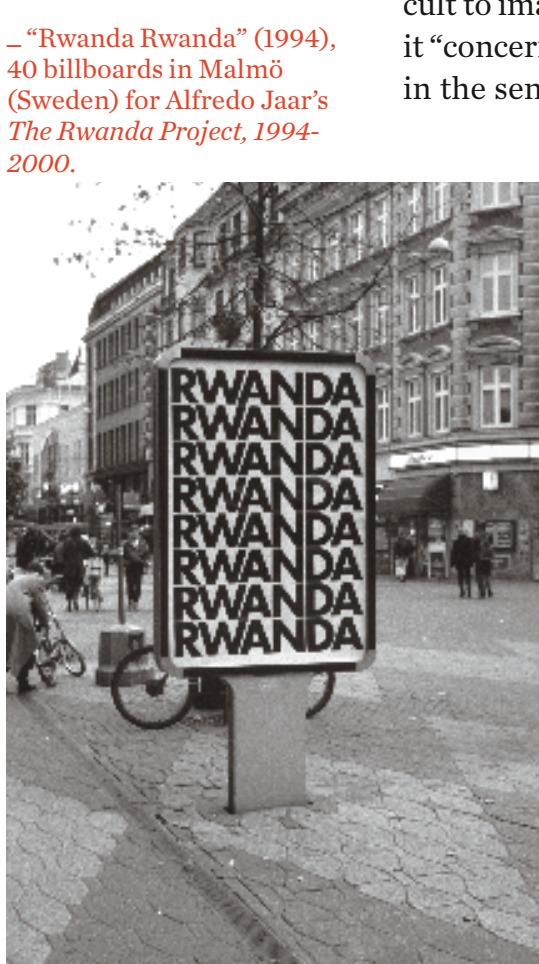

The] personal experience [of the witness] should be an example, amongst others, of the catastrophe he recounts: it is essential that the witness has exposed himself to risks, or that he is one of the victims of the documented upheaval. In his single person are united a story, an interpretation and above all a personal experience which underwrites this interpretation.

The genre of testimony is based on a pact. The witness "was there", has seen and experienced events -catastrophic events - that are unknown to the audience, and The or she succeds in connecting the individual level with the collective. The reported personal experience must corroborate a more general thesis about history - an "interpretation", as Riffaterre calls it, or a "public narrative" (Baker 2006, 38) - and constitute a "lesson" for the audience. Others emphasize that a testimony is not a simple "transfer of information", a static report on verifiable facts, but constitutes an ethical act, as the witness "incarnates" a truth about history and becomes a "living memory" (Dulong 1998, 11-15; Coquio 2003, 27-28). Literary testimony, then, is the representation of this act.

Traditionally, literature, and literary testimony in particular, has refused and resisted the perpetrator's point of view. Unlike that of the victim-witness, it is difficult to imagine that the personal narrative of a killer could have a moral aim - that it "concerns us". As Catherine Coquio points out, the perpetrator is not a "witness" the sense of the word as it is understood in literary testimony. Citing Giorgio Agamben's distinction between testis (a witness who intervenes as a third party, often in a legal context) and superstes (one who has lived through an experience and underscores the ethical significance of the testimony), she concludes that perpetrators are neither testis nor superstes. They simply cannot be witnesses (testis) to crime they have themselves committed. Referring to the testimonies of Adolf Eichmann and Rudolf Höss, Coquio argues that Holocaust perpetrators have "testified to no "catastrophe' whatsoever" They peris "They merely commented "in a documentary way" upon their "difficult an demanding job" (2003,29), unable to imagine an internal perspective on the events and to actually live through the experience (superstes). This raises complex moral questions for both writers and readers. I it moral to give killers the opportunity to speak for themselves, and is it moral to listen to what a killer has to say? Can one understanc without forgiving, explain without justifying, enter the "dark heart" of history without becoming a voyeur? Indeed, the very possibility of the killer's testimony is disquieting. How can a person be capable of telling this kind of story and voicing the ultimate transgression? Why do killers choose to test Why do kils che to testify, what do they want to achieve with their stories, and what are the precise conditions and circumstances
of their prise de parole?
Catherine Milkovitch-Rioux has argued that literature can actually "bear witness" to the perpetrator's story but, given the formal and ethical aporias, it cannot be done in the first degree. This "extreme form of literature", as she labels it, requires an elaborate mise en scène $(2010,193)$, implying that the killer's story somehow needs to be mediated or "translated", that is, "voiced" by another narrative instance. This paper focuses on the role and position of the author who "voices" the perpetrator's perspective. It explores the interweaving of literature and ethics and the role of mediation and of translation as a form of mediation, in the literary text. Drawingon (n) narrative theory and discouse analysis, it offers a conceptual framework with which to analyze the (re)presentation of the perpetrator's testinony in Jean Hatzfeld's Une saison de machettes (2003), the second book in a trilogy on the Rwandan genocide. ${ }^{2}$ It also analyzes excerpts from English $(M E)$ and Dutch $(M D)$ translations of Une saison de machettes $(M)$. The paper demonstrates how these different forms of mediation - and the polyphonic nature of the perpetrators' discourse which they reveal - challenge the view, promoted by Hatzfeld himself, of the possibility of a "consonant" translation.

GIVING THE PERPETRATOR A VOICE IN UNE SAISON DE MACHETTES

Hatzfeld is known in France as a war reporter who travelled throughout eastern Europe in the late 1980s and reported in 1994 on the Rwandan genocide for the newspaper Libération. A few years after his visit to Rwanda, Hatzfeld decided to newspaper Libération. A few years after his visit to Rwanda, Hatzfeld decided to
recast his journalistic work as a literary project. "As a reporter, I failed", he stated in an interview in 2007, "because I simply didn't understand at the time" (Hatzfeld 2007). Following the publication of the first book in his trilogy, Dans le nu de la vie, readers expressed an interest in the killers' point of view and wanted to know, Hatzfeld explains, "what had gone on in the mind of the killers" (ME 38). The author therefore decided to interview a gang of condemned Hutu killers in the Rilima prison who agreed to speak about their activities during the massacres, describing their first murders and the routine job of hunting in the marshes with machetes In Une saison me machettes, Hatzeld prosison de machettes, génocidaires. Though for Hatzfeld the killers' stories raised moral questions rather than answers, he felt there was something to learn from them. "In some confused way", he admits, "[the killers] are also probably trying to emphasize, to all of us at the edge of that exterminating whirlwind, an agonizing truth" (ME 229). Although this "agonizing truth" was not incompatible with invention, imagination or lies, Hatzfeld believed that the killers' stories could "reflect a more essential truth" (ME 130) about the atmosphere and the mentality of the men at the time of the massacres. At the same time, however, Hatzfeld admits to scepticism and embarrassment about this project and questions its moral acceptability. The ethical complexities that are evident in the perpetrators' testimonies compel Hatzfeld to intervene in their arexts - to present and represent their stories while making sure of displayng own position in relation to the stories he recounts. He is very present in the text of
(2) Hatzfeld's first book, Dans le nu de la vie, published in
2000 , recounts the stories of the 2000, recounts the stories of the La Stratégie des antilopes, tells the story of Hatzfeld's return to Rwanda in 2007 to reflect on the "Reconciliation" policy
that condemned survivors and released perpetrators to 
Une saison de machettes, continuously contextualizing, commenting and correcting the killers' stories, using various discursive strategies to explicitly distance himself from his interlocutors - linguistically and morally - and intervene in the narratives they propose.

Mona Baker has argued that mediators "face a basic ethical choice with every assignment: to reproduce existing ideologies as encoded in the narratives elaborated in the text or utterance, or to dissociate themselves from those ideologies" (2006, 105). Writers who mediate the perpetrators' discourse can resort to strategies that llow the the allow them to dissociate themselves from the position of the killer and inject the discourse with their own voice, thereby actively "framing" the narrative, consciously pitching discursive cues to manipulate the interpretation of the story they recount (110). Hatzfeld's framing of the killers' discourse allows him to speak with a voice of his own - to produce a counter discourse which "compensates" for his decision to give the perpetrators a platform. This form of mediation activity involves an "active process of signification" (Baker 2006, 106). It is a form of re-narration (see Bake 2008) that produces a shift, an intervention, a crack in the univocal text, thus challenging Hatzfeld's illusion of an authentic discourse in which the reader can "hear the voice" of the perpetrator as distinct from the author-narrator's own. In the case of Une saison de machettes, a further mediating lement was involved. In Hatzfeld's original French version, the interviews and subsequent transcriptions were, in some cases, undertaken with the help of an interpreter, Innocent Rwililiza, a 38-year-old teacher, and involved the translation of Kinyarwanda to Rwandan French, a mediating process which Hatzfeld describes as "innocent" and "transparent".

According to Theo Hermans, "voice" in translation is an "index of [...] discursive presence" $(2010,198)$. Discourse is here defined as an open and productive concept, neither limited to speech acts nor to public representations, but apprehended in its social, political and cultural dimensions. The reader can identify two differen voices in Une saison de machettes, each linked to a particular discourse. In order to analyze the discursive levels of this "relayed autobiography" I adopt the following terminology suggested by Ruth Amossy (2010). The first voice is that of the "perterning " petrator-narrator", who offers a personal narrative on his killing experiences; the second is that of the "author-narrator", re-narrating this story for his audience. The term "author-narrator" is especially appropriate in Hatzfeld's case. The book vacillates between documentary and literature, so that author and narrator are aligned to enforce the authority of the narration. In translated texts, a third voice emerges, that of the translator, which, as Hermans indicates, needs to be posited when it is not discernible. Hermans offers the following model, proposed in traditional narrative theory, to distinguish between the different voices present in a narrative account $(2010,209)$ :

(text)

[I say: (text)]

$\{$ I translate: [I say: (text)]\}
The re-narrating activity of the author-narrator Hatzfeld is also a form of transation - or at least mediation - and it therefore requires an elaboration of this model which highlights all three voices present and "audible" in the English and Dutch texts:

(text)

[I say: (text)]

$\{$ I re-narrate: [I say: (text)]\}

$<$ I translate: $\{$ I re-narrate: [I say: (text)]\}>

The importance of translation and mediation in the killers' literary testimonies and the polyphonic texts that result from it cannot be underestimated. As Hermans has indicated, translation is not, as the reproduced model might suggest, a form of "direct quotation" $(2010,196)$. An analysis of Hatzfeld's récit will indeed reveal that translation is never "noiseless". The mediating instance in Une saison de machettes is not completely external to the text; the different voices tend to intermingle, causing the reader to wonder: "what in fact are these texts, presented as the killers' testimonies?” (Kerstens 2006, 103).

\section{CONSTRUCTING A PICTURE FRAME}

Uneasy with the ethical implications of his decision to interview the génocidaires, in Une saison de machettes, Hatzfeld tries to clearly position himself against his interlocutors. He organizes the text so that the killers' testimony is framed, using the literary form to explicitly comment on the perpetrators' stories without compromising the idea of an "authentic" testimony. Though the killers' discourse is mediated and actively framed, Hatzfeld wants his readers to be able to "hear" the perpetrators' "voice" - given that Une saison de machettes is supposed to be the génocidaires' testimony, not Hatzfeld's. Despite the author's statements in interviews about his literary approach, the volume has an obvious documentary aspect which is brought out in the paratexts. Hatzfeld emphatically underscores the authenticity is brought of the interviews by adding maps of Rwanda, a chronology of the events of 1994 and biographies and photographs of the killers, complete with the sentences pronounced
by the Rwandan court - nearly all the men were released. by the Rwandan court - nearly all the men were released.

The documentary character of the work is emphasized in the English volumes, even more so than in the French original, which remains generically ambiguous. Hatzfeld's work is published in France by Seuil, as part of the series Fiction \& cie (Fiction \& Company) and is presented as a collection of récits. This term does not have a clear-cut meaning and can be used for both fictional "tales" or "stories" that are neither novels (romans) nor short stories (nouvelles), and for journalistic texts, where it means "account" or "report" (Kerstens 2006, 102). In the American publication, the subtitle A Report by Jean Hatzfeld is added, presenting the book as frontline "reportage", "trove for future histo is is a deportage", a genocide" according to excerpts from the Kirkus Review quoted on the back cover 
According to O Magazine (also quoted on the back cover), the reader can hear "the voices of the men, many of whom speak in a kind of chilling, breathtaking poetry". A blurb on the UK version refers to the text as "chilling reportage" and a "documentation of the voices of Rwandan killers". These descriptions all suggest that Hatzfeld's volume offers an unprocessed testimony of the Rwandan killers - un témoignage brut.

Hatzfeld endorses this interpretation by creating the image of a "picture frame" based on a strict demarcation of inside and outside, sugoesting that his own framing activity takes places outide the places out side the perpetrators iscourse. Though Hatzfeld is aware that his comments may effectively influence and change the meaning and functioning of the killers' discourse, he nevertheless cone nevertheless considers their testimony to be transparent nsisting on a rigorous distinction between his own voice and the voices of the men he interviews. The frame is easily discernible to the reader since it is made graphic in two

- "The Silence of 1 million slides, light table and magnifiers for Alfredo Jaar's The Rwanda Project, 1994-2000.

(3) Paul Kerstens rightly remarks
that this "may truly help to make the testimonies more real, but it may also install a hierarchy in some readers minds between
the "savant" writer Hatzefld and the "ignorant" Rwandan informant. The author thereby
involuntarly reproduces a kind typical for western dicscourse on
Africa" (Kerstens 2006, 102). ways. Firstly, the author-narrator's discourse is visually separated from the killers' by being allocated to distinct chapters, with the book alternating between chapters containing the transcribed conversations with the perpetrators and chapters written by Hatzfeld. Secondly, the distance between the author and the killers is reinforced by Hatzfeld. Secondly, the distance between the author and the killers is reinforced
in the use of language. Hatzfeld's annotations are written in a highly literary and in the use of language. Hatzfeld's annotations are written in a highly literary and almost rhetorical "Hexagonal" French - the French language as spoken in France and poetic version of French. Through this linguistic management, the reader can easily distinguish the two voices while the author guarantees the "purity" of the killers' words. ${ }^{3}$

In the end, however, the perpetrators' discourse is infused with meaning by this framing activity, revealing itself, not as a transparent given, but as Hatzfeld' this fration a the constriscourse starts to crack and the killers' voices become permeated by both the author-narrator's
voice and, in the translated texts, the voice of the translators.

\section{TRACING THE AUTHOR-NARRATOR'S VOICE: THE KILLERS' STORIES REWORKED}

Hatzfeld describes the killers' voices as repellently calm and monotone, almost chilling, as if the men did not understand the monstrosity of their crimes. The men seem undisturbed when they speak about their first killing, the distraction of hunting, the hard work in the marshes and their hope for forgiveness. Hatzfeld organizes the collected material from the interviews into eighteen "thematic" units, each dedicated to a specific aspect of the genocide. This particuar organization not only creates the illusion of a group discussion, which is inconsistent with the interview procedure outlined elsewhere (see $M E$ 140-141), it also bears no correspondence to the original chronology of the conversations. In the chapter "In the shade of an acacia", the author remarks briefly: "To broach certain very personal subjects, such as 'The First Time' or 'And God in All This?', I wait for our moments of greatest complicity, which often come at the end of our meetings, when we have grown used to one another" (ME 147). Fragments ofinterviews are med together in thematic chapters, ofinter while the telling and seeningly ironic titles manipuate the reader's interpretation of the text, for example, "Taste and distaste" (sugesting that some perpetrators took pleasure in killing), "Rejoicing in the village" (where the author comments on the looting after the killing, severely condemning the killers' greed and apparent lack of moral values), "Field work" (where killers cold-bloodedly compare cutting vegetables and "cutting" people)

and "Bargaining for forgiveness" (implying that feelings of remorse cannot be sincere). The chapters rendering the voices of the perpetrators do not reflect the original dialogues, but reproduce the men's words in a streaming monologue. This is a striking feature as readers are addressed directly by the killers, who are able to produce a torrent of words without pausing for breath. As Lee Ann Fujii remarks, what is a torrent of words without pausing for breath. As Lee Ann Fujii remarks, what is missing in his narrative is the role Hatzfeld played in shaping the killers" responses. It is not clear to what extent their words "are also a product of Hatzfeld's own handthe questions he asked, the wording he used, the way he edited the men's responses, and the way he presents those responses as uninterrupted paragraphs on the page" (Fujii 2007,156). Madelaine Hron similarly points out that these sections might well "reflect some of Hatzfeld's leading questions - the different angles he encouraged killers to elaborate in order to create a logical narrative of their murderous actions" (Hron 2007, 6-7). By turning the original, thematically fragmented dialogue into a chilling monologue on a single topic, Hatzfeld produces a particular effect. The cold-blooded accounts of the perpetrators and their apparent lack of self-awareness seem designed to horrify and repel the reader. 
TRACING THE INTERPPETER'S VOICE: THE TRANSPARENCY AND POLYPHONY OF THE FRAME

In Une saison de machettes, Hatzfeld parenthetically states that, in his first book, Dans le nu de la vie, he did not detail the exact circumstances of his conversations with the Rwandan people, including the role of translation. In Dansle nu de la vie, he mentions only that three languages were involved in the interview process: "firstly Kinyarwanda other people and by translators, and finally French itself [lefrançais de l'Hexagone] (English translation 2005, 3). In Une saison de machettes, Hatzfeld reflects a little more on the role of translation (ME 141):

When the tape recorder is turned on, the interview begins, in [Rwandan] French, or in Kinyarwanda (the Rwandan language) translated by Innocent. On this subject, reader might well question the influence of the translator on the distinctive language of the speakers. Innocent understood that a transcription of the recorded material in extenso was the necessary first step, from oral to written oral testimony. I have to say that he then translated the testimony given in Kinyarwanda so faithfully and so well that itisimpossible,

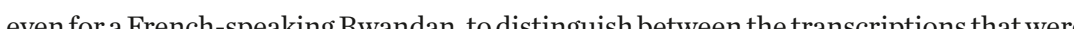
trang

Several observations can be made on the basis of this excerpt. First, Hatzfeld reveals that the killers expressed themselves either in Rwandan French or in Kinyarwanda, the mother tongue of the majority of the people, and that his translator Innocent, translated Kinyarwanda into Rwandan French during the interviews and later helped to create the transcriptions. Second, Hatzfeld adheres to a rather naïve conception of translation when he claims that Innocent translated the killers' words "so faithfully and so well" that it was impossible to distinguish between those stories translated from Kinyarwanda to Rwandan French, and the untranslated stories delivered directly in Rwand His comments sugeest that His commentation does not appear as a translation but "seems "natural, i.e., not translated" (Venuti 1994, 5). However, the illusion of fluency and transparency fostered by Hatzfeld is subverted by more careful consideration of the context and circumstances of the translation of the interviews. Although Hatzfeld qualifies Innocent as "a formidable translator" (ME 40), elsewhere in the volume we learn that when forme interahamwe leader Joseph-Désiré Bitero tries to present himself as a scapegoat, he is brusquely interrupted by Innocent who gives him a sound lecturing: "someone who won't confess has no right to complain" (ME 163). Innocent knows all of the men well and introduces them to Hatzfeld, for example, calling Jean Baptiste "a evil and cocky as he is crafty and intelligent" (ME 29) and claiming "I Innace was a evil and cocky he is codger and a dodger, plus he'd suddenly go nasty with the Tutsis" ( $M E 40)$. We also
learn that the interviews with the killers usually ended after two hours because at that point "either Innocent shows signs of understandable anger or I [Hatzfeld] become exasperated or - most often - disgust, boredom, or frustration destroys both his concentration and mine" (ME 141-142). It should also be noted that Innocent is himself a survivor. He has told his personal story in Dans le nu de la vie, where he evoked the death of his wife and son in the genocide. The Hutus were cruel and barbaric, he reported, because they "chopped people up instead of killing them straightaway" (English translation 2005, 75); they "had become animals", "worse because they no longer knew why they killed, and they than animals of the bush, because they no longer knew why they killed, and they did so with quirks" (73)

Innocent's voice, though, is not clearly discernible for the reader due to Hatzfeld's editing. It is never indicated which conversations needed to be translated and which were recorded and transcribed directly in Rwandan French.

\section{TRANSLATING UNE SAISON DE MACHETTES}

The final voices of mediation are the English and Dutch translators. The translation of Hatzfeld's book into these languages introduces further shifts that affect the configuration of the different voices and therefore the working of the frame. In 2005 two years after its publication in France Une saison de machettes was translated into the English as A Time for Machetes. The Rwandan Genocide - The Killers Speak (UK) and Machete Season. The Killers in Rwanda Speak (US), both with a preface by Susan Sontag. Although the titles, the descriptions of the author and his oeuvre, and the book covers and back flaps are different in each, the translation of Hatzfeld's text itself is exactly the same. Linda Coverdale was awarded the 2006 Scott Moncrieff prize for her translation and the preface to the English volumes was translated into Dutch and included in the publication Seizoen van de machetes (2004).

The presence of Rwandan French and "Hexagonal" French in Une saison de machettes, and particularly the contrast between them, was an essential strategy used by Hatzfeld to distinguish his voice from those of the perpetrators in framing his literary testimony The translators also use a number of strategies that serve in some cases, to maintain Hatzfeld's frame:

(a) Je ne crois pas que les vaches présentaient un détestable problème. ( $M 246)$
I do not believe the cows presented a truly hateful problem [...]. (ME 208) I do not believe the cows presented a truly hateful problem [...]. ( $(M E$
Ik denk niet dat de koeien zo'n groot probleem vormden. (MD 253)

(b) Des renforts et des gronderies sont arrivés pour mettre un dernier point à cette affaire [...]. (M 57-58)

Reinforcements and scoldings put the last touch on the matter [...]. (ME 46)

We kregen versterking en werden gemaand om de zaak tot een goed einde te brengen. (MD 62) 
(a), the English translator leaves the unconventional combination of détestable and problème unaltered, speaking of a "hateful problem". In (b) the nouns renfort and gronderies are used with the active form of the verbs arriver and mettre, typical of Rwandan French. Although the English translator omits the first verb, she reproduces this peculiar combination instead of replacing it with a more idiomatic phrase. Adalbert uses in this excerpt the expression mettre un dernier point (rather than mettre un point final found in standard French) and the translator imitate this deviation by writing "put the last touch" instead of "put the final touch". In this devit the by wint final "puin contrast, the linguistic variations of French that characterize Hatzfeld's frame in Une saison de machettes are missing from the Dutch translation. Readers of the Dutch text will not "hear" two distinct voices, as both Hatzfeld and the killers speak the same idiomatic Dutch. In Dutch the "hateful" problem Alphonse discusses in (a) becomes a "big" problem (een groot probleem), and in (b) the translator opts once more for an idiomatic phrase: the men "were reinforced" and "were scolded" (kregen versterking en werden gemaand).

The language of the killers is evocative and plastic, full of images generated by personifications and metaphors:

(c) La chance n'exemptait aucun Tutsi dans les marais. ( $M 134)$ Luck did not exempt a single Tutsi in the marshes. (ME 111)

In het moeras kwam geen enkele Tusi er onderuit. (MD 139)

(d) Ce massacre, on n'en parlait pas avant, parce que c'était une affaire des intimidateurs qui se préparait à l'écart des oreilles. ( $M 258)$

That massacre, we did not speak of it beforehand because it was the business of the intimidators and was being prepared outside of earshot. (ME 219)

Tevoren werd er niet over bloedbaden gesproken, dat was een zaak van de

anvoerders, die zich in het geheim voorbereidden. (MD 266)

(e) C'est surtout la terrible vie de la prison qui découpe mon sommeil. ( $M$ 179)

It's mostly this wretched prison life that cuts into my sleep. (ME 149)

Het is vooral het vreselijke gevangenisleven dat me uit mijn slaap houdt. (MD 185)

The figure of speech in (c), which renders the text slightly poetic, is reproduced in English. When Fulgence asserts in (d) that the genocide was being prepared " l'écart des oreilles", the English translator opts for "outside of earshot", thus imitat ing the non-idiomatic use of the preposition in French. In order to explain that he is haunted by nightmares, Alphonse surprisingly uses the expression "découper le sommeil" (e) - which becomes "cut into my sleep". The Dutch text, on the contrary, displays once more Théo Buckinx' preference for idiomatic languge use despite ( (i); in the genocide wa "got away" geheim); and prison life "keeps me from my sleep" (houdt me uit mijn slaap). Furthermore, the final example reveals the translator's tendency to tone down the raw vocabulary of Hatzfeld's interlocutors. Elsewhere in the text, the verb "to cut" is replaced by "to kill" (doden, MD 141), "to assassinate" (vermoorden, MD 140), or "to hit" (slagen, $M D$ 154).

Interestingly, these excerpts do not corroborate Venuti's thesis that English-language translation is dominated by the ideology of "fluency" (Venuti 1994,5; 1998,4). Quite the contrary the evocative and somewhat plastic language of the Hutu killers is rendered in marked English, and the specific syntax of Rwandan French illers is rendered in marked English, an preserved. The Engle of the author, less idiomatic, almost poetic. Readers "hear" two distinct voices and are thus made aware of linguistic differences similar to those which have constituted the basis of Hatzfeld's frame. In the Dutch text, in contrast, both the killers and the author-narrator speak the same idiomatic Dutch. The translator produces a fluent and easily readable text, thereby erasing the ethical significance of the linguistic and stylistic peculiarities of the French original. It is not clear why this strategy was adopted, but the result is evident. The text becomes stylistically "flat" and Hatzfeld's frame is sustained only by the visual separation of the authorial chapters and the killers' interviews'.

In both the English and Dutch translations, however, the illusion of a "consonant" and "coincident" translation is shattered in places where the translator's voice explicitly manifests itself and becomes "audible" for the reader. Unlike the French version, Une saison de machettes, where Innocent's voice is formally absent from the written transcriptions, in the English and Dutch texts there are a number of instances where the translator's voice emerges as an individual discursive presence. Hermans explains that this voice can be caught in the "disparities and interstices" of the text $(2010,209)$ and, more precisely, in cases of "performative self-contradiction" where the translator's traditional self-denial "runs into obvious, textually traceable contradictions" (198). It is not only a question, then, of comparing the translation to its source text but of revealing the translator's voice ( text itself

Translators can indeed feel the need to intervene in a Translator's Note in order to assure a smooth communication with their reading public while translating specific cultural references (e.g. explaining the role of parishes in Rwandan Christian society, $M E 23)$, or they can explicate certain linguistic elements that seem "intranslatable" (e.g. pointing to the - non-existing - difference between survivant and rescapé in English or Dutch, $M E$ 146; $M D$ 180). Hermans further mentions moments where the translated text calls attention to, or makes visible, the very act of translation in the target text. This occurs in the Dutch and English translated texts of Une saison de machettes, where in the original, Hatzfeld discusses the use of different variants of the French language. Hermans identifies these as moments of "self-reflexiven" " "self-referentiality", which senstize the reader to the of "self-refexiveness" and "self-refere language motif (Hermans 2010, 198).
(5) A Amore in-depth analysis
of the Engilish and Duntch translations of Une saison de

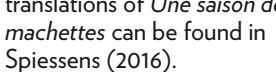




\section{OTHER WORKS CITED}

- Amossy, Ruth, 'La dimension argumentative du discours littéraire. L'exemple des Bienveillantes', in Dominique Maingueneau 4 Inger Ostenstad (eds), Concepts et démarches de lanalyse du discours littéraire, Paris.
LHHarmattan, 2010.

- Baker, Mona, Translation and Conflict. A Narrative Account, London \& New York: Routledge, 2006

-.-., 'Reframing Conflict in Translation', Social Semiotics 17(2), 2007, $151-169$.

-.-., 'Ethics of Renarration: Mona Baker Is I Interviewed by Andrew Chesterman', Cultus 1(1), 2008, 10-33. - Bourke, Joanna, An Intimate History of Killing. Face to Face Killing in $20^{\text {th }}$ Century Warfare, New York: Basic
Books, 1999.

- Coquio, Catherine, À propos d'un nihilisme contemporain: néga
trouée. Négation et témoignage, Nantes: IAtalante, 2003, 23-89.

Da Devarrieux, Claire \& Nathalie Levisalles, Les Bienveillantes, roman à controverse, Libération, 7 November 2006 .
Available at http://www.liberation.fr/evenement/010165697-les-bienveillantes-roman-a-controverse (accessed May 2016).

- Dulong, Renaud, Le Témoin ocularir. Les conditions sociales de lattestation personnelle, Paris: Éditions de
lEEHESS, 1998. - Felman, Shoshana \& Dori laub, Testimony: Crises of Witnessing in Literature, $P_{\text {sychoanalysis, and History, }}$
New York: Routledge, 1992. - Fujii, Lee Ann, 'Machete Season: The Killers in Rwanda Speak', African Studies Review 50(1), 2007, 155-156. - Gatore, Gilbert, Le Passé devant soi. Figures de la vie impossible, tome 1, Paris: Phébus, 2008,

PRIMARY REFERENCES

French

- Hatzfeld, Jean, Dans le nu de la vie. Récits des marais rwandais, Paris: Seuil, 2000.

---, Une saison de machettes. Récits, Paris: Seuil, 2003.

-.-., La Stratégie des antilopes. Récit, Paris. Seuil, 2007

English - UK

- Hatzfeld, Jean, Into the Quick ol life: The Rwandan Genocide - The Survivors Speak, translated from the French
by Gerry Feehily, London: Serpent's Tail, 2005.

-..., A Time for Machetes. The Rwandan Genocide: The Killers Speak, translated from the French by Linda
Coverdale, preface by Susan Sontag, London: Serpent's Tail, 2005. -..-, The Strategy of Antelopes: Rwanda After the Genocide, translated from the French by Linda Coverdale

Dutch

- Hatzfeld, Jean, Seizoen van de machetess. Het verhaal van de daders, translated from the French by Théo
Buckinx, Amsterdam: De Bezige Bii, 2004.

- -.-., De strategie van de antilopen. Daders en slachtofffers van de Rwandese genocide, translated from the French
by Alice Teekman, Amsterdam: De Bezige Bij, 2008.

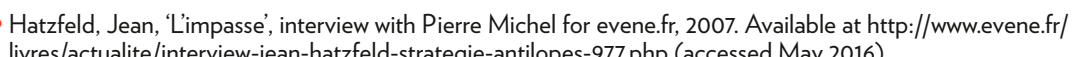

- Hermans, Theo, 'The Translator's Voice in Translated Narrative' [1996], in Mona Baker (ed.), Critical Readings in

- Hron, Madelaine, Kumaramaza? Representing the Rwandan Killer, paper presented at the $6^{\text {th }}$ Global vcce//ccee//hron\%200paper.pdf (accessed May 2016).

"Kerstens, Paul, "'Voice and Give Voice": Dialectics Between Fiction and History in Narratives on the Rwandan Genocide', International Journal of Francophone Studies 9, 2006, 93-110.

Mauvignier, Laurent, Des hommes, Paris: Minuit, 2009.

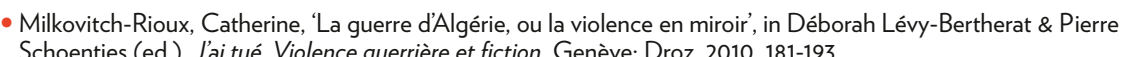

列

- Rotman, Patrick, L'ennemi intime [2002], Paris: Seuil, 2007.

- Spiessens, Anneleen, Quand le bourreau prend la parole. Témoignage et fiction, Génève: Droz, 2016.

- Venuti, Lawrence, The Translatoor's Invisibility: A History of Translation, London \& New York: Routledge, 1994.

- --., The Scandals of Translation: Towards an Ethics of Difference, London: Routledge, 1998.

- Viart, Dominique \& Bruno Vercier, La littérature française au présent, Paris: Bordas, 2008. 